\section{SEEDS}

Surrey Energy Economics

Discussion paper Series

\section{SURREY}

ENERGY

ECONOMICS

Centre

\title{
Privatising Nuclear Power: evidence for the review of future prospects for nuclear power
}

\author{
Colin Robinson
}

November 1994 
SEEC consists of members of the Department of Economics who work on energy and environmental economics. SEEC's aims include the promotion of research and teaching in the broad area of energy economics and policy. SEEC was founded in 1983. Its creation was intended to consolidate the research on energy economics which developed at the University of Surrey after the appointment of Colin Robinson to the Chair of Economics in 1968. Colin and the colleagues he attracted to the University buit up Surrey's reputation, initially with pioneering work on North Sea oil and gas, and subsequently in all the other major areas of energy economics.

- Recent research covers the following areas: Electricity, gas and coal privatisation in the UK; privatisation in the Middle East; the structure of UR energy demand, North Sea oil and gas economies and policy: intemational oil markets; electricity economics; the transport of energy; environmental policy in the UK, energy and environmental policy in the Third World; global environmental issues.

- SEEC research output includes SEEDS - Surrey Energy Economics Discussion papers Series (recent titles may be found on the backcover), as well as a range of other acadenic papers, books and monographs including SELC OCCASIONAL PAPERS.

- Each year SEEC organises a range of energy conferences and workshops on energy themes. Specialist workshops include the meetings of the Third World Energy Policy Study Group, convened by Peter Pearson and Prof. Paul Stevens (University of Dundee), and the joint SEEC/BIEE Energy Modelling Group, convened by David Hawdon and Paul Appleby (BP).

Members of SEEC provide najor inputs into the postgraduate energy courses run by the Economics Department - in particular, the M.Sc. courses on Energy Economics and Energy Policy, and the Diploma in the Economics of Energy and Development for Graduates.

Enquiries about Surrey Energy Economies Centre may be made to: Director of SEEC. Peter I G Pearson Secretary: Isobel Hildyard E-mail.P.Pearson@surrey.ac.uk E-mail:1.Hildyard@surrey.ac.uk

SEEC, Economics Dept, University of Surrey, Guildford GU2 $5 \times$, UK. Telephone: $+44-1483-259379$ Fax: $+44-1483-303775$ 


\section{Surrey Energy Economics Discussion paper Series \\ SEEDS No. 79}

Privatising Nuclear Power: evidence for the review of future prospects for nuclear power

Colin Robinson

University of Surrey and

Institute of Economic Affairs

This paper may not be reproduced without permission.

ISBN: $1-85237-145-5$

November 1994

British Library Cataloguing-in-Publication Data.

A catalogue record for this book is available from the British Library. 


\section{EXECUTIVE SUMMARY}

- Cases presented at the nuclear review concentrate on 'market failure' arguments. But the market failure approach to policy-making is discredited. As the history of British electricity supply demonstrates, government action, in the name of remedying failures, is unlikely to further the 'social interest'. Markets are effective discovery mechanisms but their action is hindered by government intervention, which inevitably discourages entrepreneurship and innovation. (1.1 to 1.3 )

o Attempts by supporters and opponents of nuclear power to make out cases on market failure grounds have been unsuccessful even in their own terms. Market failure analysis can be used to support virtually any conceivable policy, depending on the analyst's preconceptions. Most analysts under-estimate the ability of markets to deal with the problems they foresee and ignore the serious issue of government failure. (2.1 to 2.6)

- To establish a system which will stimulate nuclear plant construction when appropriate requires private ownership and a competitive market environment in which companies act as entrepreneurs rather than being bound by state rules and regulations. Some existing plant (Magnox) may have to remain in state ownership because of the difficulty of privatising it: if so, its operation should be contracted out by competitive tender for efficiency and safety reasons. (3.1 to 3.2)

- Nuclear Electric and Scottish Nuclear should be privatised not as specialist nuclear companies but as companies with generation as their main business, able to diversify to the extent their shareholders and the competition authorities permit, to sell their electricity where they choose and to determine methods of storage and processing subject to general safety rules. (3.3)

- Compromises between state and private ownership are unsatisfactory. All such halfway houses rely on methods of deciding on investments which are inappropriate in principle and which have yielded poor results in the past. (4.1) 
o The "nuclear option' will probably disappear if the industry remains nationalised. There is a bias in public sector decision-making, particularly marked at present, against long-term projects; costs will tend to be excessive because of the absence of competitive pressures; and privatised electricity companies will object to investments by a state-subsidised competitor which will significantly affect their activities. (4.2 to 4.3 )

o A future stimulus to nuclear power is more likely if the industry is in private hands. The successors to the nuclear companies would have a powerful incentive to capitalise on their comparative advantage in nuclear generation by reducing costs and enlarging the market for nuclear power. (4.4)

o After privatisation, there should not only be significant gains in productive efficiency (as in other privatised industries) but prices should move closer to costs. Over time, there would be significant benefits from entrepreneurship and innovation. (4.5)

- To realise the potential benefits of nuclear privatisation, the privatisation scheme should aim at increasing rivalry in the British electricity market and integrating the partially segregated markets of England and Wales and Scotland. To these ends, the successor companies to Nuclear Electric and Scottish Nuclear should be more equal in size than the two companies now are. The aim should be to establish two formidable competitors for National Power and PowerGen, so there is a proper 'internal market' in electricity in Britain. (4.6 to 4.7 )

- Many benefits would follow. The successors to the nuclear companies would be able to diversify and would operate free from government interference. As a more rivalrous market in electricity developed and the influence of National Power and PowerGen in the electricity pool waned, consumers should gain from lower prices and improved contract terms. They would also gain indirectly because OFFER would no longer have to supervise generation in detail and so could concentrate on regulating the network of wires and the RECs. National Power and PowerGen would be subject to less intrusive regulation. (4.8) 
- Nuclear privatisation, now feasible, would complete privatisation of electricity supply and end the anomalous situation in which there is a large state sector in a privatised industry. (5)

September 1994 


\section{INTRODUCTION}

In the 1970s, growth prospects for the nuclear industry worldwide seemed bright. A 1974 OECD report, for example, projected an expansion of nuclear capacity in the OECD area, under a 'basic programme', from 42 GW at the end of 1973 to 982 GW in 1990: given an 'accelerated programme', the report suggested 1990 capacity could be almost 1400 GW: $:^{1}$ Similar projections can be found in other documents of the time, based on the plans of governments and electrical utilities. Ten years later, the general belief was still that nuclear power was the cheapest means of generating base load power in many countries and that there would be a considerable expansion of nuclear capacity in the 1980s, if not on the scale earlier projected. ${ }^{2}$

These hopes were, of course, disappointed. In the event, 1990 nuclear capacity in the OECD area was only $262 \mathrm{GW}$ - just over one quarter the basic programme anticipated in 1974 and about one fifth of the accelerated programme. By the end of the century, OECD nuclear capacity may be less than $300 \mathrm{GW}$ and nuclear's share of world electricity generation seems, for the time being anyway, to have stabilised. In the year 2000 it may be no higher than it is today (around 17 per cent).

Nuclear prospects now seem poor in many countries. There are few new orders and some of the reactors built in the 1960s and early 1970s are nearing the ends of their lives. Anti-nuclear 'environmental' activists seem to have the upper hand and are mounting legal challenges, regulation is tightening, there are continuing technical difficulties in operating some plants, and because of past experiences industry estimates of future costs are questioned.

In Britain, the nuclear industry has had a more impressive period in the last four years than in its previous thirty-five-year history when the generating costs of new plant were invariably under-estimated and there

1 Organisation for Economic Cooperation and Development, Energy Prospects to 1985, OECD, 1974, Vol.1, Table 9.1

2 For example, see Organisation for Economic Cooperation and Development, Nuclear Energy Prospects to 2000, OECD, $1982, \mathrm{p} .7$. 
were serious operating problems. ${ }^{3}$ Because performance under nationalisation was so variable, the most appropriate comparison is with the average of the five years before privatisation (1985 89). Comparing 1993 with that period, nuclear electricity generated in the United Kingdom and available through the public supply system increased to $76.8 \mathrm{TWh}$ from 50.4 TWh (an increase of over 50 per cent), even though no new nuclear stations were opened and Berkeley (276 MW output capacity), Trawsfynydd (390 MW) and Hunterston A (300 MW) were closed. Nuclear electricity's share of primary energy consumption rose over the same period from 6 per cent to over 9 per cent and nuclear's share of electricity generated in the United Kingdom increased from 17 per cent to over 25 per cent. Nevertheless, there has been no new order since Sizewell B.

This paper examines whether there are positive ways forward for the British nuclear industry so that it can build on recent improvements in operating performance. In general, my view is that the industry should be privatised and its future determined by market forces.

Many other commentators rely on the argument that markets are not to be trusted - that 'energy is too important to be left to the market' so that there should be an energy policy which seeks to identify and remedy so-called 'market failures'. In considering the future of nuclear power, they therefore focus on what they believe to be failures in markets which distort investment decisions in the electricity supply industry and the rest of the energy market.

Because the market failure approach to policy-making is so entrenched in British economics, I begin in Section 1 with some fundamental objections of principle to this approach; the second part of Section 1 is a brief statement of the case for using energy markets, despite their apparent 'imperfections'. In Section 2 of the paper, I consider in more detail the arguments often used for supporting nuclear power. Sections 3 and 4 discuss how privatisation might best be done, the case for privatising nuclear power, and what advantages might be expected.

3 See Colin Robinson, The Power of the State: economic questions over nuclear generation, Adam Smith Institute, 1991. 


\section{MARKET FAILURES AND THE CASE FOR MARKETS}

\subsection{Remedying market failures}

The idea of a perfect market has a long history in economics: it is a useful explanatory tool with an important place in neo-classical theory. Many economists still implicitly assume there is something 'perfect' about the perfect market. They then make welfare prescriptions, based on the idea that if markets are 'imperfect' and 'fail' the answer is government intervention designed either to establish a market which is nearer to perfection or to simulate the outcome of such a perfect market (for example, by regulation).

The market failure approach to policy-making was, however, undermined many years ago. A paper by Lipsey and Lancaster in $1956^{4}$ removed the foundations of 'piecemeal welfare economics' (taking steps in one market such as energy - to move it closer to 'perfection'). According to their 'theory of second best', there is no reason to assume that community welfare can be increased by piecemeal action in one market, while other markets remain imperfect. Action in the market in question would inevitably have effects on other markets and the net result might be welfare-reducing.

More radical attacks, beginning in the late $1950 \mathrm{~s}$, came primarily from North American 'public choice' economists who analysed how choices are made in the public sector (where individuals make choices for others as well as themselves); from economists of the Chicago school who produced empirical studies of the consequences of government action; and from economists in the 'Austrian' tradition who see markets in fundamentally different terms from neo-classical theorists. The main problems which have been identified are as follows:

The impossibility of perfection: markets are always and everywhere imperfect. Information failure is pervasive because the information which market participants need for their decisions is, by definition, about the

4 R.G. Lipsey and K. Lancaster, 'The General Theory of the Second Best', Review of Economic Studies, Vol.24, 1956. 
future. Yet, since the future is unknowable, for that reason (if no other) markets are never perfect.

A doubtful optimality criterion: the Pareto optimality criterion which underlies the idea that the perfect market leads to perfect results is of doubtful value. It is a minimalist principle under which a policy move is desirable if at least one person becomes better off whilst no one else is worse off. In practice, virtually any policy move involves both winners and losers: who is then to say whether the loss to the losers is greater or less than the gain to the winners? The problem is circumvented, but not properly addressed, by the arbitrary conventions of cost-benefit analysis, where it is generally assumed that, if total gain exceeds total loss, a policy move is desirable because the gainers could compensate the losers and still be better off.

Government failure: just as there is no such thing as a perfect market, there is no such thing as a perfect government. Like all human institutions, governments are imperfect and they invariably fail. Public choice economists analyse actions by people in the public sector on the assumption that they are motivated in much the same way as people in the private sector, ${ }^{5}$ whereas neo-classical economics tends to assume that governments are disinterested servants of the public good. Public choice analysts conclude that governments are not primarily concerned with pursuing the 'national interest', even if they could perceive what that elusive concept is in any particular case. Politicians are vote-seekers, operating in a political marketplace in which decisions are based on very short term considerations, are heavily influenced by organised producer pressure groups, and give little weight to the interests of unorganised consumers. Civil servants also pursue personal interests: they are usually supposed to seek power, prestige and influence and perhaps to be engaged in maximising their departmental budgets. A serious monopoly issue arises in government action, according to public choice economists. Governments have a monopoly of policy-making between elections, they have powers

5 See, for example, Anthony Downs, An Economic Theory of Democracy, Harper, 1957; Gordon Tullock, The Vote Motive, Institute of Economic Affairs, 1976 and 1978; The Economics of Politics, Institute of Economic Affairs, 1978; W.C.Mitchell, Government As It Is, Institute of Economic Affairs, 1988; and Arthur Seldon, 'Politicians for or against the people', in Gerard Radnitzky and Hardy Bouillon, Government: Servant or Master, Rodopi, 1993. 
beyond those of any private monopoly to coerce other people and they have access to a near-bottomless purse (other people's money) to put their policies into effect. Increasing government action therefore implies increasing monopolisation of decision-making and reducing freedom of citizens.

Adverse consequences of government action: there are now many well-documented cases of how actions by governments and public sector bodies (including regulators) tend to have unfortunate effects. Government attempts to 'pick winners' in Britain in the 1960s come to mind as well as the whole history of energy policy in this country. ${ }^{6}$ In the United States, regulation which was established to protect the 'public interest' tended to further the interests of the industries which were regulated or of the regulators themselves. ${ }^{7}$

The arguments above cast serious doubt on the market failure case for government action. A perfect market cannot exist so why should it be the aim of policy? Taking action in one market may not lead to any improvement in welfare even if one assumes that government action is far-sighted and disinterested. In practice, governments have short time-horizons and people within government as well as in the private sector are most likely pursuing their own interests. Governments have considerable monopoly power and so the results of their actions are unlikely to further the social interest as does the pursuit of private interest in competitive industries: indeed, the restriction of freedom which most government action implies represents a significant external cost.

6 Colin Robinson, Energy Policy: Errors, Illusions and Market Realities, Institute of Economic Affairs, Occasional Paper 90, 1993.

7 G.J. Stigler, 'The Theory of Economic Regulation', Bell Journal of Economics and Management Science, Vol.2, 1971, and S. Peltzman, 'The Economic Theory of Regulation After a Decade of Deregulation', in M.N. Bailey and C. Winston (eds.), Brookings Papers in Economic Activity: Microeconomics 1989, Brookings Institution, 1989. 


\subsection{A Positive case for markets}

As well as the negative case against government action outlined above, there is a positive case for using markets. It rests principally on their characteristics as discovery processes. It has been put mainly by 'Austrian' economists, and particularly F.A. Hayek, though in recent times some natural scientists have reached similar conclusions using analogies between economic and biological processes. ${ }^{8}$

According to this view, whether or not markets are 'perfect' is irrelevant - there is nothing genuinely perfect or even particularly desirable about the perfect markets of elementary economics textbooks. A succinct statement of the Austrian 'market process' view is the following by Israel Kirzner:

'What keeps the market process in motion is competition - not competition in the sense of "perfect competition", in which perfect knowledge is combined with very large numbers of buyers and sellers to generate a state of perennial equilibrium - but competition as the rivalrous activities of market participants trying to win profits by offering the market better opportunities than are currently available. The existence of rivalrous competition requires not large numbers of buyers and sellers but simply freedom of entry. .. The competitive market process occurs because equilibrium has not yet been attained'.?

One of the fundamental reasons why markets work beneficially relates to their role as producers of new knowledge. According to the Austrian view, knowledge is essentially dispersed: by definition, it cannot be gathered together in the hands of a few clever people in Whitehall or elsewhere, so all forms of centralised forecasting, planning and target setting are doomed to fail.

New knowledge arises as a consequence of market processes. As experience demonstrates, no one knows the future. We are all ignorant: we do not even know what we do not know. This dilemma is, strictly

8 David Parker and Ralph Stacey, Chaos, Management and Economics, Institute of Economic Affairs, Hobart Paper No.125, 1994, and Michael L. Rothschild, Bionomics: The Inevitability of Capitalism, London: Futura Publications, 1992.

9 Israel M. Kirzner, 'The Perils of Regulation: A Market Process Approach', in Discovery and the Capitalist Process, University of Chicago Press, 1985, p.130. 
speaking, insoluble. Each person must make forecasts, explicit or implicit, in order to run his or her life, yet forecasting is impossible. A competitive market, however, helps solve this awkward problem because it is a knowledge-creator - a mechanism for producing information which otherwise would not exist.

Knowledge is created because, given the incentives which people and organisations have when they are operating in rivalry one with another, they will constantly search for new ways of doing things. The actions of entrepreneurs, who discover improved means of satisfying consumers so as to gain advantage over their competitors, bring advances in the technologies of production, management and other activities.

Moreover, markets will co-ordinate actions which otherwise could not have been co-ordinated, they will stimulate efficiency to an extent otherwise unachievable and they will allow a degree of freedom of choice otherwise unrealisable. The market process works essentially by transmitting information (principally via price signals) from consumers to producers and back again.

Consumers have the power of exit from suppliers which do not suit them and so enjoy greater security of supply and lower prices than when they are in the hands of monopolists (state or other). Minorities find their wants are met in ways which a political marketplace (which serves the majority) is incapable of reproducing. Producers find that efficiency standards are automatically set for them by the actions of competitors because they cannot afford to fall behind. Thus there is a constant stimulus to innovation and entrepreneurship which promotes economic progress.

Because markets are discovery mechanisms, their results cannot be reproduced by regulation, government control or similar means. Whitehall or other planners, unaided by the discovery process, will face an impenetrable barrier - the impossibility of centralised forecasting. The knowledge which market processes would have produced will not appear because the results of competitive markets can be achieved only by the process of discovery. Thus governments and their agents cannot engage successfully in central planning, or even in 'investment co-ordination'. Markets co-ordinate millions of decisions through the price system. Governments may prepare plans but they cannot usefully co-ordinate 
investment decisions because they do not (and can not) have the knowledge to do so.

Such arguments for markets are a long way from the old-fashioned textbook case that one should aim to achieve a desirable state called a 'perfect market'. The competitive market is not a state but a process of discovery in which millions of people participate which stimulates the flow of new knowledge.

Markets are not superior in everything. Government is the prime (though not necessarily the sole) instrument for providing law and order and national defence, establishing and maintaining property rights, promoting and sustaining competition and - quite important in the energy field where one of Britain's oldest-established industries has for years been in decline for tempering the effects of decline and providing a safety net for the disadvantaged. But most governments stray far outside such bounds because of the incentives of the political process.

In my view, the market failure case for government action is not sustainable. It stems from an 'equilibrium' view of the world which is of little value when disequilibrium is the norm. There is a powerful argument for using markets to the maximum extent feasible, based not on the assumption that they are perfect but on their "discovery" characteristics. They are the best means available of maintaining a prosperous and progressive society in which people have a reasonable degree of freedom. They may appear 'imperfect' to intellectuals who would like to force their own preferences on to other people. But the alternative of extensive government intervention has in the past led to inefficiency, waste and interference with people's lives, not because of obvious errors which future governments can readily correct, but because of the inherent characteristics of such action.

Though the idea of an energy policy - whether or not it supports nuclear power-seems superficially attractive, in practice it is subject to all the objections discussed above. There is no reason to believe that pursuit of such a policy in the energy sector would be beneficial to the British economy and society as a whole; there would be winners but there would also be losers who would be uncompensated; government or its agents would undoubtedly fail in pursuing the chosen objectives so there would 
be unintended consequences; most serious of all, the market process would be hindered because many of the contracts which parties would otherwise have entered into would founder and entrepreneurial activity would be discouraged.

\subsection{Electricity supply: market process versus nationalisation}

Britain's electricity supply industry provides an instructive case study of the consequences of suppressing market processes and how, once a market is established, desirable changes occur.

As part of the market process, companies appear in order to meet demands from consumers. They flourish if they meet those demands successfully and they have a natural tendency to diversify in order to reduce risks. A company with its main business in electricity generation, for example, would diversify by avoiding dependence on a particular fuel, on a few sources of supply, on particular technologies and on one or a few trades unions. It might also move into related business activities at home or overseas.

The market process in UK electricity supply was, however, suppressed for over forty years under nationalisation (and, before that, during a period of state supervision in the inter-war years). After nationalisation, the very extensive state interference - of which many leading figures in the industry complained - soon began. Prices were controlled - for example, in the 1970 s they were held down and in the 1980s they were raised beyond what the industry wanted - and the government intervened in investment programmes. Moreover, the industry's ability to diversify was severely constrained.

Electricity supply came to be the government's main instrument in carrying out an energy policy which differed little between the two major parties and consisted broadly of supporting coal and promoting nuclear power. ${ }^{10}$ It was easier to persuade the leaders of electricity supply to burn more coal than they wanted and to construct more nuclear plant than to use taxes, subsidies and direct controls (which might have violated international trading obligations). Resistance from the electricity supply 
industry was muted because it was either compensated direct by government or, because of its monopoly power, it passed the costs on to consumers. In effect, the government chose the industry's fuel mix: electricity and other energy consumers and taxpayers footed the bill.

Consequently the fuel mix became quite different from what would have been chosen by competing private companies trying to satisfy consumers, including providing them with continuity of supply. After various excursions into oil generation (most notably just before the oil 'crises' of the 1970s), on the eve of privatisation the industry in the United Kingdom was left with a plant capacity mix (60 per cent coal, 17 per cent oil, 11 per cent nuclear, and 12 per cent hydro and gas turbines) which seemed totally inappropriate for the 1990s. The actions of the generators and RECs in England and Wales demonstrate their view of that mix: immediately they were privatised, they diversified away from coal by investing in the gas plant which government policy had prohibited them from building in earlier years.

The 'dash for gas' was not entirely a consequence of competitive market forces. But there is no doubt that generators and distribution companies felt impelled to diversify, for the benefit of their shareholders and their consumers, away from the plant mix which government policy had bequeathed them. More diverse sources of fuel supply and technologies of production increased security, as did the decline of central wage bargaining which had in the past tended to exaggerate the effects of disputes and potential disputes.

EC environmental regulations pushed the privatised companies in the same direction. The concentration on coal which had resulted from British government policy under nationalisation meant that the electricity supply industry's impact on the environment was far worse than it would have been had it been able freely to choose its fuel sources.

Even though it is only four years since electricity privatisation - and the privatisation scheme was rather poorly conceived - considerable diversification has already taken place, for security and environmental reasons, in the private sector of the industry. Coal's share of fuel used by major power producers fell from 69 per cent in 1989 to 54 per cent in the first half of 1994 whereas the share of gas rose from zero to 12 per cent. 
The two English generators are increasing their overseas activities. Each private company is using its new-found freedom to change the scope of its business. In the nature of the market process, the companies are not all going in the same direction. Some of the RECs, for example, are moving out of retail appliance sales and contracting whereas others are increasing their commitment to such activities.

The two nuclear companies, however, still suffer from an inability to diversify. They are being left behind the privatised sector of the industry. They can increase the efficiency of existing activities, as they have very successfully done, but they are unable significantly to change the nature of those activities, moving out of existing fields in directions where market forces might lead.

\section{THE MARKET FAILURE APPROACH AND THE CASES FOR AND AGAINST NUCLEAR POWER}

Both promoters of nuclear power and their opponents use market failure arguments, either explicitly or implicitly, to support their cases.

Proponents claim, in effect, that the presence of failures justifies 'over-investment' in nuclear power: that is, more investment should be induced - by means of subsidies, taxes on substitutes or direct controls than there would be in presently structured markets. The principal failures invoked are the supposed inability of markets to foresee and adjust to future increases in fossil fuel prices; the external environmental effects of fossil fuel combustion, especially its alleged effect in enhancing global warming; and the supply instability which they associate with fossil fuels. ${ }^{11}$

Opponents argue the contrary - that the relevant market failures are such that 'too much' will be invested in nuclear power if it is left to markets. Therefore, 'under-investment' is justified: in one way or another penalties

11 See, for example, Nuclear Electric's evidence to the Nuclear Review, especially Volume 2, The Environmental and Strategic Benefits of Nuclear Power, June 1994, and British Nuclear Industry Forum, Keeping our Energy Options Open: the case for nuclear power, July 1994. 
should be imposed on nuclear power. Generally, the case is made in terms of the environmental and other externalities of nuclear power. It is claimed that investing in nuclear power means leaving future generations with an intractable nuclear waste problem; that there are dangers from 'routine' releases both of waste and of radiation; that stockpiles of plutonium and other material capable of being used for weapons constitute a weapons proliferation threat; and that there is an ever-present danger of accident at nuclear power stations and associated facilities.

Opponents also claim that estimates of future nuclear generation costs are over-optimistic and that there are cheaper ways of countering the threats which supporters of nuclear power foresee.

My view, as explained in Section 1, is that there are fundamental objections to the market failure approach to policy-making. But even if, for the sake of argument, one accepts the general approach, neither the supporters nor the opponents of nuclear power makes out a good case. Indeed, their sharply contrasting conclusions cast doubt on the whole approach as a practical means of analysis. If, in the case of nuclear power, it can yield two diametrically opposed views of what policy should be, of what value is it? The general problem of applying market failure analysis is that there is so much uncertainty about what constitutes 'failures' (since all the relevant failures lie in the future) and so much difficulty in quantifying them, that a very wide range of answers invariably emerges. Thus the analysis can be used to support virtually any conceivable policy, depending on analysts' preconceptions.

To fix the point more clearly, I discuss below some of the major 'failures' which are said to justify supporting nuclear power. I take these particular 'failures' because they have been prominent in public discussion, not because I think the case for support is less plausible than the arguments for penalising nuclear power. As explained above, I do not think a case has been made (or can be made) on market failure grounds either for supporting or for penalising nuclear investment. The claim made by opponents of nuclear power that nuclear generating costs are under-estimated is best addressed by leaving nuclear investment decisions to the market: that is the only way cost standards can be established, as Section 3 below explains. 


\subsection{Resource scarcity}

The first commonly perceived problem is rising energy demand and the pressure on energy resources which will supposedly result unless nuclear power is promoted. The popular belief is that markets are myopic, unable to foresee and cope with such problems. Long-term energy forecasts are, however, almost totally discredited. There have been many such forecasts in the past, containing apocalyptic predictions of resource inadequacy, ${ }^{12}$ all of them wildly inaccurate. It is beyond human capacity to make useful forecasts so far ahead; in any case, they invariably disregard or under-estimate the adjustment capability of the economic system. For about 150 years, the trend of real fossil fuel prices has been downwards, ${ }^{13}$ though there have been periods when prices have risen (the 1970s) or fallen (the 1980s) substantially. In one of the more volatile markets - crude oil - prices are much lower now than they were when oil was first exploited by drilling in the United States in the 1860s: in the last few years crude prices (in 1992 dollars) have been within the range of about $\$ 10-20$ per barrel within which they have fluctuated for most of the period since 1870 .

Despite past evidence, there is a popular belief in the inherent tendency of oil, gas and coal prices to rise in the long term because of increasing scarcity and increasing costs. For example, the belief that gas prices must rise in the long term is now widespread. Some of the early classical economists (for example, David Ricardo) can be quoted in support of such views. But their theoretical basis rests on the assumption that technology remains unchanged. In the event, there have been massive advances in extraction and managerial technology which have counteracted any tendency for costs to increase. So the view that extraction costs and prices will rise in the future depends on the assumption that the rate of technological advance will decline relative to the underlying rate of cost increase.

12 For example, D. Meadows et al., The Limits to Growth, Earth Island, 1972. For examples of more recent forecasts, see those made regularly by the World Energy Council. Resource Scarcity, Johns Hopkins, 1963. 
Moreover, price increases usually contain the seeds of their own destruction: they are not persistent trends but relatively short-lived cycles. When a resource is expected to become scarce (for example, crude oil in the 1970s) prices increase, consumption falls, profits from production rise, the demand for substitutes increases, technology improves and eventually the supply of the resource in question rises relative to dernand. By such a process the world oil market moved from apparent scarcity (at going prices) to huge surplus in the space of little more than ten years from the early 1970 s to the early 1980 s. $^{14}$

Even if it were true (which I doubt) that by early next century supplies of gas or other fossil fuels will appear scarce, the implicit assumption that markets cannot cope with approaching scarcity - is incorrect. If a resource is expected to become scarce, those expectations induce producers to hold their resource in the ground, thus boosting current prices and conserving the resource for future generations. The chain of events outlined above for the oil market then comes into play. The apparent scarcity may disappear over a period of years, as in the case of oil in the 1970 s, so that the price increase is only temporary.

If there were a more serious underlying scarcity of fossil fuels, the price increase would persist and market processes would promote the substitution of other energy sources, including nuclear power. These processes may be 'imperfect' but they are sure. The alternative of political action is not at all attractive. It is likely that participants in markets, who are risking their own money, will make better forecasts than will governments. Expectations of scarcity will promote self-interested action which eventually avoids that scarcity. Years?', in D. Hawdon (ed.), The Energy Crisis, Ten Years After, Croom Helm, 1984. 


\subsection{Global warming}

The prospect of global warming is another reason given for supporting investment in nuclear power. However, the problem appears to have been exaggerated by those pressure groups (environmental lobbies, some research scientists, some energy and environmental economists, for example) which stand to gain from policies to counter global warming. The evidence that there is a warming tendency appears very weak. ${ }^{15}$ Reliable statistics are not available for a period long enough for trends in world temperature to be distinguished from cycles so it is unclear whether there is a warming trend. Moreover, there is considerable scientific debate about the accuracy with which world temperature was measured before satellite measurements became available, about the basis for claims that carbon dioxide and other emissions will necessarily result in warming, and about the degree of warming associated with any given quantity of emissions. The models which are used to predict warming are poor at 'predicting' the past and seem inadequate to deal with such a complex phenomenon.

Even if a general warming tendency were to be established, its consequences depend on how the effect is distributed across the globe and whether it occurs mainly by day or by night. There would be winners and losers and it is not clear that the result would be a net loss of welfare for the world. There is debate also about the appropriate response to any such tendency. It might be less costly to adapt than to try to avert any warming trend.

A favoured argument at present appeals to a 'precautionary principle'. The contention is that, even if there is no clear evidence of a warming trend, action should be taken - on the insurance principle - in case warming is occurring. Such arguments seem superficially attractive. But the danger is that they will lead to very costly action - such as heavy taxes on fossil fuels to reduce their use - to guard against an extremely unlikely eventuality.

15 Robert Balling, The Heated Debate: Greenhouse Predictions Versus Climate Reality, Pacific Research Institute, 1992, and Roger Bate and Julian Morris, Global Warming: Apocalypse or Llot Air, Institute of Economic Affairs, Studies on the Environment No.1, 1994. 


\subsection{Supply instability}

Another 'Iong-term energy problem' - which is claimed to justify support for nuclear power - is the perceived instability of many energy supply regions, such as the former Soviet Union. Fear of supply insecurity is a long-standing concern in debates about energy policy though in the past the main fear was that OPEC oil producers would disrupt supplies.

In practice, supply interruptions from overseas have been few and far between. British energy supply problems (and, just as important, expensive actions intended to counter those problems such as holding excess stocks) have arisen principally because of strikes (actual and threatened) in the state-owned coal industry. The problem has been largely of the government's own making: by protecting coal-mining, mainly by insisting that the electricity generating industry become dependent on it, government increased coal's monopoly power and promoted insecurity. ${ }^{16}$ The insecurity to which government action in Britain led was no aberration. Protection of home suppliers is bound to enhance their monopoly power and, in general, will be security-reducing. Security is best achieved by the natural diversification tendencies of markets. Producers and consumers have an interest in continuity of supply; they are capable of judging which sources are most likely to offer continuity and of avoiding undue dependence on one or a few sources. The evidence suggests that governments, subject to interest group pressures and with many objectives other than security-provision, are not so successful.

\subsection{Apocalyptic predictions and central action}

A more general objection to much of what is written about long-term energy concerns is as follows. At least since the middle of the nineteenth century, apocalyptic papers have been written about the energy dangers which lie ahead, and in particular about the possibility of exhaustion of some or all energy resources. Obviously, one can always find possible worries in the energy outlook, if only because the future is unknowable. Potential dangers always lurk around the corner. Some fuels might rise sharply in price, there might be serious difficulties with some technologies,

16 Colin Robinson and Eileen Marshall, Can Coal be Saved?, Institute of Economic Affairs, Hobart Paper No.105; 1985. 
political instabilities might cut supplies from some countries, some emissions to the atmosphere might turn out to have irreversible effects. It is certain some problems will arise some time in the future, though not necessarily the ones which people now identify. The real issue is how best to cope with problems when they do arise - via markets or through central action?

Many people recommend central action because to do so makes them appear concerned and busy in solving the world's problems. But, as explained above, there are fundamental philosophical objections to such action. Moreover, its record is very poor. As recently as the early 1980 s, expensive programmes to replace oil by coal, nuclear power and other fuels were being formulated by governments - most of them, thankfully, never fully implemented - under the illusion that only central action could solve the long-term shortage of crude oil which 'experts' assured them would appear in the future. ${ }^{17}$ In the event, the 'crisis' disappeared almost entirely as a consequence of market forces. Market participants have more incentive to deal with emerging problems than do governments. It is, after all, by dealing with such problems better than their competitors that they make profits.

\subsection{Dangers of intervention}

For the reasons I have given, I doubt whether one can justify support for nuclear power on market failure grounds. Most people who argue for such support - and those who argue the opposite case that nuclear power should in some way be penalised or even banned - seem to me to be working on the false assumption that there are obvious ways in which energy markets should be modified which can readily be perceived by a group of experts which considers the matter for a little while.

The danger of intervention in energy markets is that it will inhibit desirable market functions - in particular, that it will hinder the market discovery process. It is easy to say that the government or some agency

17 See, for example, Carrol L. Wilson, Coal - Bridge to the Future, Ballinger, 1980, which claimed a "...massive effort to expand facilities for the production, transport and use of coal is urgently required to provide for even moderate economic growth in the world between now and the year 2000 '. 
should take a 'long-term view', that it should 'co-ordinate investment', that it should act in the 'national interest'. But, in practice, attempting to perform such actions raises unanswerable questions. How long is a long-term view? Given that it is human myopia, not market fallure, that stops people taking long-term views, how can one find superior beings who can see far into the future? How can investment be co-ordinated when the information needed for co-ordination can be produced only by a market? How can such a vague concept as 'the national interest' be made operational?

There is confusion between planning at the company level and government planning. Any prudent company will prepare plans, based on scenarios, which are as robust as it can manage. There will be numerous such plans in the economy as a whole and indeed there will be competition in planning within a competitive industry. That is fundamentally different from some central body setting out views of the future, not stemming from market processes, which others are supposed to take into account. It is most unlikely that such an exercise can be useful when the forecasters have no stake in the outcome (as do companies which make plans).

Over-riding the market in the case of nuclear power - whether to invest more or less than the market would provide - runs the risk of reverting to an electricity supply industry subject to extensive government interference in its fuel choice decisions with similar unfortunate results to those so obvious before privatisation (see 1.3 above).

\subsection{Government failure}

My criticisms of the market failure case do not imply approval of the present structure of energy markets in Britain. Both the gas and electricity privatisation schemes were, in my view, seriously flawed and their deficiencies are only gradually being remedied. Assuming that the gas market will be opened to significant competition, the main problem in the British energy market is distortions in electricity supply because of the effects of the generating duopoly in England and Wales (which were partly responsible for the 'dash for gas'), the support still given to nuclear power, and the fuel oil tax. Although the power of the generators is being curbed by the regulator, some of the most serious effects of these distortions have already fallen on coal: given the characteristics of the 
electricity market, the rate of decline of the British coal industry has probably been more rapid than would have occurred in a genuinely competitive market. ${ }^{18}$

The source of recent problems is not failure in markets but failure in government. The way forward is, in my view, to make electricity and other energy markets more competitive with greater rivalry among the players - not to revert to interventionist policies which failed so badly in earlier postwar years. As I explain in Sections 3 and 4, which consider privatisation of the nuclear industry, an important advantage of privatising nuclear power is that it would be a means of significantly enhancing competition in electricity generation.

\section{PRIVATISATION: THE GENERAL APPROACH}

\subsection{Issues in privatisation}

When privatisation of nuclear power was rejected in 1989 , the (then) $\mathrm{Mr}$. Wakeham said the private sector was seeking 'unprecedented guarantees' and that he was '...not willing to underwrite the private sector in this way'. ${ }^{19}$ The difficulties of privatisation are not so great as they were in 1989 - the operating performance of existing plants has improved as explained earlier, and because of experience with Sizewell B there are fewer doubts about the nuclear industry's ability to construct plants to time and to cost. Nevertheless, some awkward issues remain - in particular what to do with Magnox stations and the associated liabilities.

In such circumstances, it may not be possible to privatise all nuclear plant and so the privatisation scheme will probably have to distinguish between two issues:

- providing incentives for the efficient and safe operation of existing plant

Energy Policy; Errors, lllusions and Market Realities, op. cit., pp.46-48. 
o establishing a system which will stimulate new nuclear plant construction in appropriate circumstances

To deal with the second issue, in my view, requires private ownership and a competitive market environment in which companies act as entrepreneurs to take advantage of market opportunities rather than being bound by state rules and regulations.

But the first objective can probably be achieved under continued state ownership of some existing plant, provided there is a contracting-out system which allows private companies to compete to operate the plant. Contracting out is now a well-established means of increasing efficiency in the public sector. If full privatisation is too difficult, the privatisation scheme can concentrate on private ownership where it matters most - in new plant construction. Rather than retain the whole of the nuclear sector in state hands, it would be better to privatise those assets which can be privatised, leaving the rest (which have limited lives anyway) in the hands of the state.

\subsection{Contracting out for Magnox?}

One possible scheme would be to retain Magnox stations in state ownership, privatising the AGRs (which should now be possible given their much improved performance) and the Sizewell PWR, relying on the market to judge when new building is required. Financial markets would then not have make judgments about the riskiness of companies which own Magnox.

A case can be made for leaving Magnox plants in state hands on the grounds that they are the consequences of economic and technological decisions made when the electricity supply industry was nationalised and its choices of energy sources and technologies were heavily influenced by governments. Government, on behalf of taxpayers, would have the responsibility of ensuring that the nuclear assets in state ownership were operated as efficiently and safely as possible. To fulfil these aims, it would contract out by competitive tender the running of those stations. To ensure a smooth transition in a way which provided a continuing incentive for efficiency improvements and safe operation, it would be desirable to give 
the successors of Nuclear Electric and Scottish Nuclear exclusive contracts for a limited initial period.

The two companies could, for example, be franchised for (say) five years to operate the state-owned nuclear power stations and sell the electricity from those stations. Or the companies could act as contractors, working for a fee related to the efficiency improvements they achieved, and the revenues from electricity sales could go direct to the state.

At the end of the initial period, the franchise or contract would be thrown open to competitive bidding for another period: there would be a quality hurdle for potential bidders who would have to demonstrate competence to operate nuclear facilities. Under the new regime, an attempt would be made to avoid monopoly in the supply of services at any stage of the nuclear fuel cycle (such as BNFL now enjoys in fuel supply and processing). Contracts or franchises could be divided so that day-to-day running of plant was separated from functions such as decommissioning and other back-end activities. Companies would bid a cash sum (or possibly a royalty) based on their evaluation of the net present value of the cash flows over the franchise or contract period. The successors of Scottish Nuclear and Nuclear Electric would, of course, be permitted to bid in competition with other companies from Britain and abroad.

Because of the time-limit on the contract or franchise, there would be an incentive to increase efficiency and to promote safety during the initial period, just as the prospect of the nuclear review has spurred the two companies into efficiency increases during the four years since the rest of the electricity industry was privatised.

The two companies are already as much like contractors or franchisees as commercial companies. They are constrained by very tight rules - over operating, waste disposal and decommissioning safety, geographical area of activities and nature of business as well as the usual Treasury rules about investment. They are, in effect, prohibited from diversifying outside their existing business and geographical areas of activity and so have little of the freedom which companies normally enjoy to take advantage of market opportunities and to act as entrepreneurs. 


\subsection{Differences from the present}

Under the suggested form of privatisation, however, the big difference compared with the present is that the successors of Nuclear Electric and Scottish Nuclear would be in the private sector, with generation as their main business but not confined solely to nuclear power. As Section 4 explains, there would be advantages in forming successor companies more equal in size than Nuclear Electric and Scottish Nuclear are at present.

The two companies would be privatised not as specialist nuclear companies but as companies with generation as their main business, initially deriving a cash flow from contracts to operate existing nuclear facilities. Value at privatisation would depend on how the financial markets valued those contracts, their view of the prospects of more such contracts being obtained and their view of the outlook in the generation business generally. The companies could build nuclear, CCGT, coal or oil stations in Britain or abroad, purchase existing stations or convert existing nuclear stations to other fuels. Indeed, they would be able to diversify to the extent their shareholders (and the competition authorities) allowed. They would be free to sell the electricity they produced where they could find a market. They would also be free to choose, subject to general safety rules, whether or not to reprocess fuel, what methods of storage to use, and generally be able to manage the back-end services they require. Funds for investment would arise from the cash flow from operating existing nuclear assets and from borrowing. The City would view them as much less risky than companies confined to nuclear generation.

At present, the companies might not invest in new nuclear power stations, preferring to diversify their activities. But at some time the climate may be propitious for building more nuclear plant (see Section 4). The market would then signal opportunities for companies with expertise in nuclear generation. At that time, the successors of Scottish Nuclear and Nuclear Electric would be in a strong position to build competitive new plant (the full costs of which, including back-end costs, they would bear) as compared with generating companies without recent nuclear experience.

In the meantime, market processes would give both companies incentives to discover market opportunities for nuclear power and to innovate to take advantage of those opportunities. The nature of these processes and the 
benefits of privatisation to the companies and to others are examined further in Section 4 below.

\section{THE ADVANTAGES OF PRIVATISATION}

I begin with the terms of reference the government has set for its nuclear review.

\subsection{The terms of reference for the review}

The emphasis on private finance - including possible privatisation - in the terms of reference for the nuclear review represents a significant change of emphasis in official pronouncements about the nuclear industry. For the first time since 1989 , the government is willing seriously to contemplate privatisation as an option.

In 1989, privatisation was, in effect, vetoed by the capital markets not just because of the level of nuclear generating costs revealed in the debates about electricity privatisation but because of their apparently alarming escalation. As The Financial Times remarked at the time:

$\therefore .$. it was the uncertainties as much as the level of costs which caused a near-rebellion among City advisers, which have watched US private utilities being driven to the edge of bankruptcy by nuclear financial liabilities' ${ }^{20}$

The statement by Mr. John (now Lord) Wakeham on 9 November 1989 , said the government would '... wish to review the prospects for nuclear power as the Sizewell project nears completion in $1994^{\prime}{ }^{21}$ But until recently there was no hint that privatisation would be revived. The 1993 Coal Review, 22 for example, which was primarily concerned with whether existing nuclear plant should continue to operate, implicitly assumed that nuclear generation is inherently a public sector activity: investment proposals for existing or new plant should therefore be

The Financial Times, 10 November 1989.

21 Text of a statement by Rt. Hon. John Wakeham, op. cit., p.4.

22. Department of Trade and Industry, The Prospects for Coal: Conclusions of the Government's Coal Review, Cm.2235, March 1993. 
evaluated by the central assessment of avoidable costs relative to other forms of generation and by the identification of externalities.

The terms of reference mention a number of possible means of introducing private finance. But, for the reasons given below, it seems to me that privatisation is the only genuine way forward for the British nuclear industry. Compromises between state and private ownership which would bring more 'commercial freedom' to the two nuclear companies or attempt to inject some private finance into the nuclear industry would, in practice, lead to continued political interference in decision-making. Proposals to construct new plant, to extend lives of existing stations or to make other investments would spring from political not market processes.

These apparent halfway houses must necessarily rely on a method of deciding on investments which is inappropriate in principle and which has yielded poor results in the past. The basis for such decisions would still be estimates of future levelised costs provided by the industry and 'checked' by civil servants. But, in the absence of a competitive market, there are no relevant standards which allow these checks to be made. The unfortunate history of nuclear cost forecasts, made under such conditions, speaks for itself. The "economic and commercial viability of new nuclear stations", which the review is supposed to examine, is unlikely to be established except by placing the nuclear industry in a situation in which the capital markets judge its proposals and it must sell its product in rivalry with other generators.

I explain below in more detail the problems which are likely if civil nuclear power remains nationalised. I then discuss the advantages of privatisation, to consumers, the nuclear industry, and to the electricity regulator, including how it could help remedy the defects of the electricity privatisation scheme by enhancing competition in generation. 


\subsection{Death by nationalisation?}

The future of British nuclear power in the state sector looks bleak: the industry could well face a lingering death if it remains nationalised for much longer. The 'nuclear option' which the government evidently wishes to preserve will therefore most likely disappear.

One reason is the bias which exists in 'public sector' decision-making against projects (such as power plants) with expected long-term pay-offs because:

- politicians' time horizons are naturally short because of electoral processes and, within the civil service, the Treasury - concerned principally with short-term budgetary matters - dominates decisions on public sector investment programmes.

o in competitive markets, cost standards are set for companies by the activities of their competitors. Such standards are generally absent in the state sector (though competitive tendering can help to set them). Politicians and civil servants have no way of knowing what costs 'should' be. Nevertheless, they tend to be very wary of large projects because their champions have a history of under-estimating costs.

These biases exist at the best of times. But these are not the best of times for state organisations, all of which are at present constrained, and may well be so for many years ahead, by the growing pressure on government finances, mainly because of the demands of the welfare state. Politicians of all parties and the Treasury are confronted with a rising demand for state-provided services which are low-cost or zero-cost to the consumer at a time when government borrowing is already very high and when the tax burden has been increasing.

It is hardly surprising in those circumstances that government adopts a particularly sceptical attitude towards public spending proposals. Investments in energy, transport or elsewhere which mean spending large sums now but offer only long pay-back periods (with any benefits accruing to a future government, perhaps of another political party) appear especially unattractive. 
Following from the above, there are two main consequences of retaining in the state sector activities which could be in the private sector:

o large-scale long-term investments will tend to be neglected and there will be considerable friction between public sector managements and government over such projects. Managements of public sector enterprises which, like their private sector counterparts, try to take a long-term view, are bound to clash with politicians and officials whose interest lies primarily in the short term. Moreover, the absence of useful information about costs means that debate between government and project champions is sterile. Public sector managements feel frustrated by what they perceive as poor-quality, superficial evaluations of their investment proposals and by the subsequent rejection of favoured projects.

- because of the absence of competitive pressure to set cost standards, the costs of projects which do go ahead will probably be excessive compared with what could have been achieved in a more competitive environment.

For such reasons, the state sector is an uncomfortable place for an industry which relies for its survival on large long-term investments. Life as a state industry may seem superficially attractive because for a time it offers a degree of protection and a source of low-cost finance for investment. But in the longer term, history (for example, of the British coal industry ${ }^{23}$ ) suggests protection will not be maintained and the organisation will not be able to carry out its investment plans. The judges of its investment programme will not think long term and, particularly at the present time, they will not welcome proposals to spend large sums.

Energy Policy; Errors, Mlusions and Market Realities, op. cit., pp.14-50. 


\subsection{Nuclear extinction?}

Given these political and economic circumstances, a nuclear industry which remains in the state sector could, whatever the convictions of its leaders about the advantages of nuclear power, be faced not with expansion but with contraction to the point of extinction. The chances of its being allowed to build a new plant while still in the state sector seem low.

In addition to the reluctance of governments to commit funds to such a project, there is the attitude of the privatised electricity companies and their shareholders to consider. They will, with some reason, object to a new nuclear station which they will see as a state-subsidised competitor (because of the relatively low interest rate on state-funded projects even if the nuclear levy and the Scottish nuclear contracts come to an end) which would pre-empt base load power because of its comparatively low avoidable costs. So long as nuclear power is nationalised, co-existence with the private electricity supply industry will be difficult and nuclear expansion is always likely to be opposed because of the very large impact it would have on the private sector.

There will soon be a temporary boost to capacity in England and Wales with the commissioning of Sizewell B but the prospect from then onwards may well be of decline as remaining Magnox plant is decommissioned and eventually the AGRs are also closed. Twenty-five years from now (which is not a long time horizon for an energy industry) the nuclear industry in England and Wales could consist of only an aging Sizewell B and the Scottish industry might have disappeared. The appearance of another 'energy crisis' in the meantime might save the nuclear industry but that is a slender thread on which to rest its hopes, especially since decision-making in the state sector is so inflexible that response to such a crisis might take an inordinate length of time.

Privatisation is, in my view, a necessary (but not sufficient) condition for Nuclear Electric and Scottish Nuclear to develop successful businesses which would meet the needs of consumers. Instead of watching their businesses run down, with their main hope that an energy 'crisis' might one day stimulate politicians into allowing an expansion of their activities, they could take a pro-active, entrepreneurial attitude. Life in the private 
sector would produce different threats from those they now face. But the threats would be accompanied by significant opportunities of a kind not available to nationalised corporations. It would be up to the companies whether they seized them.

As compared with continuing state ownership, privatisation would free the nuclear companies from Treasury rules, reduce the politicisation of decisions which plagues all nationalised corporations and allow the companies to diversify. The benefits of privatisation to the two companies are explored in more detail in 4.9 below.

\subsection{A propitious climate for nuclear expansion and company response}

One important consideration is that, if the climate ever becomes propitious for new nuclear plant construction, there should be companies capable of taking advantage of such circumstances. One possibility is that fossil fuel prices might begin to increase and be expected to increase further. The timing of such an event is unpredictable. But resource markets tend to move in long and irregular cycles, in which expectations of plenty are replaced by fears of shortage which in turn are replaced by expectations of surplus. So the chances are that the present state of surplus (at existing prices) will for a time disappear and that such price increases will one day occur. Unless there has been a disaster in the nuclear industries in the meantime (such as a serious accident), one market response will be to stimulate new nuclear construction programmes.

Other possible changes which might result in a business environment ready for nuclear expansion are significant reductions in actual and expected costs of nuclear generation (for example, because of technical advance) or enhanced concern about the environmental impact of fossil fuel combustion.

In any of these circumstances which would make nuclear power more attractive, a state-owned nuclear industry would have to try to persuade its political masters to permit the building of more plant. Past experience suggests the response would be slow. Privately owned companies which had nuclear expertise but were not confined to nuclear plant would be in much stronger positions to respond quickly to the investment opportunity (though they would presumably still have to go through planning 
procedures). They would be working with market forces and so should be able to raise the necessary finance through the markets. In any case, because they would be diversified and less dependent on nuclear power than companies whose sole business was nuclear generation they would appear less risky than such specialised companies.

A stimulus to nuclear power is indeed more likely if the industry is in private hands than if it remains nationalised because significant cost-reducing technological advance appears more probable. Diversified though the companies would become after privatisation, they would retain a comparative advantage in nuclear generation and would therefore have a powerful incentive to innovate to press home that advantage by enlarging the market for nuclear power - for example, by designing smaller nuclear plants which are quicker to build and can be incorporated in relatively small electricity systems and by reducing back-end and other costs. There is little incentive to enlarge a market which is protected by the state.

The new companies would compete with each other and with other generators (some of which might some day move into nuclear generation) to reduce costs and prices. Some of the R \& D they would carry out might well spill over into improvements in the operating efficiency of existing plant. They would try to anticipate fuel price movements and other trends which would affect the competitive positions of different fuels. It would be surprising if their response times were not much shorter than is possible in the public sector.

\subsection{General benefits of privatisation}

Privatising the nuclear companies as well as the rest of the electricity supply industry would, in my view, bring considerable benefits which can be summarised as follows:

- There should be significant gains in productive efficiency as the companies move into the market for corporate control and become subject to shareholder pressure and the threat of take-over. Even though Nuclear Electric and Scottish Nuclear have improved their performance a great deal since the rest of the industry was privatised, experience with other privatised corporations suggests that shareholder pressure for greater efficiency is far more powerful 
than any efforts by the Treasury. Government control is inherently ineffective because, as explained earlier, in the absence of a competitive market, civil servants and politicians can have no idea what costs 'should' be.

- Provided the product market is competitive, prices will move closer to costs - reductions in costs will be passed on to consumers in a rivalrous market where companies are vying to satisfy the wants of consumers.

- Gains in productive and allocative efficiency need not be confined to the nuclear sector of electricity supply. There are some potentially very large spillover benefits from nuclear privatisation to the rest of the industry because an appropriate form of privatisation could greatly enhance competition in generation and in the supply of electricity. The greatest weakness of electricity privatisation was its failure to establish genuine rivalry in generation: nuclear privatisation could help remedy the deficiencies of the privatisation scheme.

o More important than any 'static' gains would be the dynamic benefits from greater entrepreneurship and innovation (emphasised earlier in this paper and explained below) which would appear over a period of many years.

\subsection{The structure of generation}

To realise the potential gains from nuclear privatisation, and in particular to obtain the spillover benefits mentioned above, the post-privatisation structure of electricity generation should provide for more rivalry in the British electricity market than now exists and should aim to integrate the partially segregated markets of England and Wales and Scotland.

If the government is to achieve these aims, it will have to resist the inevitable calls from centralisers in government and the academic world who will use a variety of fallacious arguments - for instance, that one big nuclear company is required to capture economies of scale, to provide Britain with a product champion which can compete internationally, and so on. The monopolisation of decisions (and information on which 
decisions must be based) in the British nuclear industry has, in the past, been a major problem ${ }^{24}$ and there is no reason to expect experience to improve. A merger of the existing two nuclear companies seems particularly inappropriate since Nuclear Electric will, after Sizewell B is commissioned, already have the 25 per cent market share usually considered necessary (but not sufficient) for a Monopolies and Mergers Commission investigation. A merged company would most likely be larger than PowerGen and might approach the size of National Power.

One means of promoting rivalry would be to offer for sale all nuclear power stations, allowing generators and others (including managers of Nuclear Electric and Scottish Nuclear) to bid for whichever assets they chose. National Power and PowerGen would be prohibited from bidding on the grounds that the regulator is already trying to avoid undue concentration in the generation sector. The result of such an auction might be to create a number of specialist nuclear companies or to diversify several existing companies into nuclear generation. Although appealing in the sense that it appears to be a market solution it might, given the existing structure of generation, result in increased influence for National Power and PowerGen relative to other generators.

A better solution, in terms of ensuring that the companies which emerge enhance competition both in the pool and in contract markets, is probably to sell off two nuclear companies of more equal size than the present two, by allocating to Scottish Nuclear prior to the sale some of Nuclear Electric's AGRs. The existing division of plant is a consequence of a rushed decision at the time the government decided not to privatise nuclear power in 1989: it should aim, on privatisation, to establish two substantial companies rather than one large one and one small one. I explain below some of the likely effects, including those on the electricity pool. 


\subsection{Accelerating the onset of competition}

Competition in generation is, of course, increasing anyway. There are many new entrants, with CCGT plant, even if many of them are associated with RECs in England and Wales. But there are widespread complaints, especially from large users, that they are receiving little benefit from privatisation, mainly because National Power and PowerGen are seen still to be setting prices in the electricity pool. It may be some years before the dominance of the two companies is significantly reduced.

One significant difference between electricity and both gas and telecommunications is that there has been no major competition-enhancing breakthrough to help the regulator. In all privatised utility markets, regulators - though hampered by privatisation structures which left incumbents with considerable market power - have used their competition-promotion duties to ease entry. Outside electricity they have, however, had considerable assistance. In telecommunications, major technical advances which undermined the 'natural monopoly' in the network of wires have made it easier for British Telecom's competitors to enter the market. Gas has lacked such technical advances but two MMC reports (especially the second in August 1993 ${ }^{25}$ ) and an OFT enquiry in 1991 have led to changes which will soon significantly reduce the strength of British Gas's monopoly position, assuming the government is not diverted from its plans.

There has, so far, been no comparable event in electricity - no technological advance, similar to that in telecommunications and no $\mathrm{MMC}$ report. OFFER has an uphill task trying to supervise a very complex industry in which it has to oversee not only the "natural monopoly" network of wires but also the generation sector because of the widespread perception that the two major generators in England and Wales have excessive market power.

Another difference between electricity and the other privatised utilities is that the others have no equivalent of the artificial (and presently compulsory) market of the electricity pool. That arrangement gives

25 Monopolies and Mergers Commission, Gas and British Gas plc, Cm.2314-2317, London: HMSO, August 1993. 
National Power and PowerGen a greater dominance than would be predicted merely by examining their market shares.

The most important benefits of privatisation are those which will appear in the long term. In electricity generation and supply there would be dynamic gains from greater entrepreneurship and innovation if the whole electricity supply industry were liberalised and in private hands. There would be benefits to energy consumers in general as diversification occurred through market processes instead of being forced on consumers by protection: prices should fall and security of energy supply should improve.

More specifically, the immediate issue which nuclear privatisation, in the form suggested above, would address is as follows. Even though there are six major generators in the British electricity market (National Power, PowerGen, Scottish Power, Hydro-Electric, Nuclear Electric and Scottish Nuclear) as well as numerous smaller recent entrants, the degree of rivalry is much less than it could be given the structure of the market and the number of players. So many constraints have been imposed (for example, on fuel choice and geographical areas of operation) that competition is far below its potential. Nuclear privatisation could remove many of these barriers to competition, establishing the 'internal market' in electricity in Britain which does not exist at present and thereby realising the dynamic gains.

At present both Nuclear Electric and Scottish Nuclear are severely hampered by their inability to diversify. Each is confined to generate from only one energy source in only one part of Britain. No company can possibly flourish in such circumstances: successful companies follow where markets lead, taking up new opportunities by diversifying their activities. It is impossible to be entrepreneurial and innovative, given the confines within which the nuclear companies operate (which do not, of course, apply to their competitors). Lifting the constraints which hinder Scottish Nuclear and Nuclear Electric would make them into far more formidable competitors for other generators than they are now. It is because the successors of Nuclear Electric and Scottish Nuclear would be much better able to realise their potential than the two companies can at present that nuclear privatisation should significantly increase rivalry in generation and supply throughout the British electricity market. 


\subsection{The benefits specified}

Under the new regime, the principal specific benefits would be as follows:

To the two companies

o they would be able to diversify energy sources for generation. The two successor 'nuclear' companies would be able to build gas, coal, oil, nuclear or renewable power stations in Britain or abroad; they could purchase existing stations (including the 6GW which is supposed to be on offer from National Power and PowerGen); they could convert nuclear stations to other energy sources if they wished. They would have complete freedom to supply their product to consumers. They would be able to take up whatever diversification opportunities appeared, subject to shareholder approval. Though they would move outside the apparent 'safety' of the state sector, the chance to follow market opportunities, rather than being confined to the nuclear business, would give them the potential to flourish in a way at present impossible.

o there would be less political interference in their decisions. They would operate within regulatory regimes laid down by government and the industry regulator. There would, presumably, be specific safety and other regulations for the nuclear side of their business. But otherwise - and quite unlike the past - they would act free of political and civil service interference. The companies would, for example, be free to choose the fuel storage or reprocessing methods they expected to be lowest-cost, subject to minimum safety standards.

o there would no longer be geographical constraints on their activities in Britain. There would be an end to the geographical market-sharing (and competition-limiting) regime, under which, because of the NEA, Scottish-generated nuclear power is confined to Scotland and Nuclear Electric's output is mainly confined to the England and Wales market because of its contract with the RECs.

o... with removal of virtually all devices which protect various fuels in the power generation market (see below), the new rivalrous market 
would have a natural tendency to diversify into nuclear power, because companies and consumers would wish to avoid dependence on coal and natural gas.

\section{To consumers}

o the successors of Scottish Nuclear and Nuclear Electric strengthened by their ability to diversify fuels, by the reduction in political interference and by the opportunity to sell their product where they want - would provide much more competition for existing generators than the two companies do in the present contrived market. The 'nuclear' companies would be particularly effective competitors since they have sites, on which new power plant could be located, already connected to the grid and they know how the electricity market functions. In other words, they have already surmounted some of the most important entry barriers which confront potential market entrants.

o the increase in competition should bring down prices to consumers and make suppliers more responsive to the contract terms consumers want. The two successor companies would become influential in setting prices and contract terms in the British electricity market as a whole (and perhaps in Northern Ireland with the inter-connector in operation), including prices in the pool. At present Nuclear Electric is essentially a price-taker in the pool (though it now sells into the contract market) and Scottish Nuclear does not sell outside Scotland.

Under the new regime, in their nuclear generation role, the two companies would be competing for base load. For example, as Scottish Nuclear began to compete for base load in England and Wales, given the relatively low avoidable costs of AGRs, some other plant would be pushed on to lower load, thus increasing rivalry among owners of mid-merit plant. As diversified generators, the two new companies would also compete for mid- and perhaps higher-merit plant: even in their nuclear role they might do so since the loss of a protected market would give them an incentive to operate nuclear plant more flexibly. The general effect would be to reduce the influence of National Power and PowerGen in pool price setting. Another advantage is that there would be more competition to offer larger customers contracts tailored more closely to their requirements. 
Domestic consumers should also benefit. With the appearance of competition for domestic consumers, given the slender margins in the supply business, there is likely to be pressure on the wholesale electricity market for lower prices which will be more effective the more generators there are.

- the increase in rivalry among companies with different ideas would diversify energy sources for generation, generation technologies and sites, thus providing increased security of supply for consumers.

o there would be a more certain end to protection in the market for electricity generation fuels. Many of the protective devices for nuclear power are due to end in 1998, so one might argue that electricity consumers will benefit anyway from that year onwards as the costs of protection are lifted. But privatisation would make the end of protection in 1998 more likely: inevitably consumers, large and small, who stand to benefit are at present uncertain whether it really will cease.

o the government could add to benefits to consumers if, in order to reinforce the liberalising effects of nuclear privatisation, it announced removal of all existing measures which constrain competition among energy sources for generation, whether nuclear or other. That is, in England and Wales, the arrangements to fulfil the NFFO up to 1998 would cease - the quota system for premium-priced nuclear-generated electricity, the contract between the RECs and Nuclear Electric which supports the NFFO, and the levy which reimburses the RECs for the additional costs of nuclear power. The tax on fuel oil for power generation would also be removed. The 15-year contracts for renewables (which are a relatively minor constraint on competition) would presurnably have to continue. 


\section{To the industry regulator}

o the regulator's task in regulating the existing very complex electricity market would be simplified by a narrowing of the scope of regulation. Once there was genuine rivalry in generation, he would be able to concentrate on tasks appropriate to a regulator of 'natural monopoly' activities. OFFER would no longer need to supervise generation closely (apart from a general oversight to ensure competition is maintained) because competition would safeguard the interests of consumers. Much of OFFER's resources have been taken up in the supervision of generation: since the first pool price enquiry (published in December 1991) it has conducted four other time-consuming investigations of the generation sector. It would be able to concentrate on the primary tasks of regulating the natural monopoly network of wires and of ensuring that the RECs do not exploit consumers in the period before competition to supply small consumers develops.

\section{To the two major generators in England and Wales}

- National Power and PowerGen must by now be concerned at the extent to which they are being regulated. The government's original intention seems to have been that regulation of the generators would be light because there would be sufficient competition to make detailed supervision unnecessary. But, as explained above, the regulator has felt bound to intervene on several occasions in their affairs. National Power and PowerGen may by now feel (as British Gas felt when it instigated a reference of the gas industry to the MMC in 1992) that they would gain from less intrusive regulation (which will arrive only with the onset of much increased competition).

The generators and their shareholders would also no longer need to be concerned that state-subsidised competitors would encroach on their market. 


\section{CONCLUSIONS}

In my view, the 'market failure' arguments which dominate most of the cases presented at the nuclear review are a dead end. Both supporters and opponents of nuclear power use such arguments in support of their opinions even though the market failure approach to policy-making is discredited in theory and in practice. Even within the confines of that approach, their cases lack substance. Moreover, over-riding the market whether to invest more or less in nuclear power than markets would provide - runs the risk of regressing to an electricity supply industry subject to extensive government interference with similar unfortunate results to those in the premprivatisation period.

Instead of trying to draw conclusions from such inherently inconclusive arguments, it seems to me the government should proceed speedily to privatise nuclear power. In the last four years, the nuclear companies have considerably improved their performance both in operating existing stations and in constructing new ones. Privatisation of most of the industry should now be feasible, though the aging Magnox stations may well have to be left in state ownership: their operation could be contracted out to ensure they are run as efficiently and safely as possible.

One consequence of not privatising is, in my view, that the 'nuclear option' will probably be lost. The state planning apparatus for nuclear power - which has governed nuclear power programmes in Britain for almost forty years - appears to have survived privatisation of the rest of the electricity supply industry. Nevertheless, for the reasons given in Section 4 above, it seems to me unlikely that any new plant will be built under the existing regime.

By contrast, privatisation - which would place producers of nuclear electricity in a market in which they had to satisfy private shareholders and sell their product in competition with others - would provide a more genuine test of the future of nuclear power than can ever be achieved by committees of Ministers, civil servants and industry representatives trying to plan that future.

On privatisation, all protection for different generation fuels (including nuclear power) should, in my view, cease. The nuclear companies would, 
however, be freed from the severe constraints which now hamper their activities, stopping them from diversifying and from being entrepreneurial and innovative. One big advantage of nuclear privatisation, is that the companies - able to follow where markets lead rather than being confined by government directions - would become far more formidable competitors for National Power and PowerGen. Consequently, not only would the successors to the two nuclear companies achieve significant efficiency gains, rivalry in generation and supply of electricity would increase throughout the British electricity market with beneficial results for consumers.

Consumers, large and small, would gain from more effective competition in generation and supply both in terms of lower prices and of contractual terms geared more closely to individual requirements. Supplies should become more secure because rivalry would produce more diversity of energy sources, generation technologies and sites. There would be a natural tendency at some stage to diversify into nuclear power to avoid undue dependence on natural gas and coal: the successors to the nuclear companies would be in a strong position to take advantage of any revival in the fortunes of nuclear power and indeed would have a strong incentive to promote such a revival.

As well as these direct advantages to consumers, there would be a significant indirect advantage since the task of the electricity regulator would become considerably easier - and regulation to protect consumers would become more effective - if rivalry in generation was promoted by nuclear privatisation. There would be no need to supervise generation in the detail which has so far been necessary. OFFER would be able to concentrate on regulating the network of wires and ensuring the RECs do not exploit consumers in the period before competition to supply small consumers develops.

In 1989 the government's retreat from its original intention to privatise nuclear power was understandable, given the serious practical problems which then existed. Circumstances have now changed. It should complete the privatisation of the British electricity supply industry, end the anomalous situation in which there is a large state enclave within the industry and bring the price and other benefits to consumers which have been discussed in this paper. 




\section{SURREY WNERGX HCONOMICS DISCUSSION PAPERS SERIES (SEEDS) and SERC OCCASTONAU PAPERS}

\section{SEEDS Nümber:}

79. Privatising Nuclear Power: evidence for the teview of future prospects

for nuclear power

Colin Robinson

ISBN 1852371455 . November 1994

78. Energy, Exterialites and Environmental Quality. Will Development

Cure the Ills it Creates?

Peter J.G. Pearson

ISBN 1852371447: October 1994

77 . The Demand for Car Fuel Efficency: An Hiedonic Price Approach

Robert Wit

76 Economies and the Envitonment The Shadow Price of

Greenhouse Gases and Aerosols

David Maddison $\quad$ ISBN 1852371412 July 1994

75. End Use Elasticities

Joseph G Hirschberg

74 A Model of Relative Price Elasticities from the Second.

Moments of Demand

Joseph 6 Hirschberg

ISBN 1852371390

Jine 1994

13 Liberalisation of the Enetgy Market: A Favourable

Supply-side Shock for the UK Economy

Colin Robinson

June 1994

SEEC OCCASTONAL PAPER

No.1. The Future of UK Energy Demaind - The S.E.E.C. United Kingdom Eilergy Demand Forecast (1903-2000)

Roger Fonquet, David Hawdon, Peter I G Pearson, Colin Robinson and Paul Sievens

ISBN 185237134X 16 December 1993

72 Recent Studies of the Demand for Energy in the UR

D Hawdon (Ed): Joyce Dargay, Roger Fouquet, Andrew Henley,

Keith Miller and John Peirson ISBN 1852371331 November 1993

71 . An Econometrie Study of the Benand for Gasoline in the Guif

Cooperation Council Countries

$M$ Nagy Eltony and Mohammad AInahmeed

ISBN 1852371315 . October 1993 
SURREY ENERGI FCONOMICS DISCUSSION PADER SMRIES (Contd)

SEEDS Number

70 International Batgaining and the EC Large Combustion Plant Directive Roger Fouquet, 0 July 1993

69 Fuels for Electricity Supply after the UK Coal Review.

Petet Pearson (Ed). Anthony Bake, Nigel Evans, DMS lones

and Coln Robinson: : ISBN 1852371099

May 1993

68. Electricity in the Third World

Peter Pearson (Ed) Andrew Barnet, Gerald Foley Prancis MeGowan

and Peter Pearson

ISBN 1852371080

Masy 1993

67. The Economies of Pil Closures in the UR

Peter Peatson (Ed) 3 papers by Anthony Baket et 1

ISBN 1852371064

January 1993

66 The Political Economy of Energy Privatisation

Colin Robinson

December 1992

65 Acid Deposition and Global Warming sinulating energy envionment economy interactions in the JK with END AM? Bavid Hawdon and Peter Pearson ISBN 1852370971 Jine 1993

64 Blectricity Picing: Cument Practice and Euture Developments:

D Hawdon. 6 Marshall and $R$ Orson

ISBN 1852370807

Jine 1992

63 Prospects for Oil P ilees in 1992 and Beyond

T. Caddy, D Hawdon, $R$. Jordan, $P$ Stevens and I Toalster

ISBN 1852370777

Miay 1992

62 . The Results of UR Electicit) Pivatisation

Colin Robinson

ISBN 1852370769

March 1992

61 Energy. Trends and the Development of Energy Paliey in the United

Kingdom

Colin Robinson

ISBN 1852370750

Februaty 1992

60 Environment, Energy Efficiency and the Third World

P J 6 P earson (Ed) 4 papers by M Bell et al

ISBN 1852370734

Octeber 1991

Details of 1 59 , prices and annul subscription Scheme on request 